Review paper

\title{
The decomposition of ectomycorrhizal fungal necromass
}

\author{
Christopher W. Fernandez a, b, *, J. Adam Langley ${ }^{\text {c }}$, Samantha Chapman ${ }^{\text {c }}$, \\ M. Luke McCormack ${ }^{\mathrm{a}, \mathrm{d}}$, Roger T. Koide ${ }^{\mathrm{e}}$
}

a Department of Plant Biology, University Minnesota, Twin Cities, United States

${ }^{\mathrm{b}}$ Department of Ecology, Evolution, and Behavior, University of Minnesota, Twin Cities, United States

${ }^{c}$ Department of Biology, Villanova University, United States

${ }^{\mathrm{d}}$ Key Laboratory of Ecosystem Network Observation and Modeling, Institute of Geographic Sciences and Natural Resources Research, Chinese Academy of Sciences, China

e Department of Biology, Brigham Young University, United States

\section{A R T I C L E I N F O}

\section{Article history:}

Received 13 July 2015

Received in revised form

22 October 2015

Accepted 23 October 2015

Available online 10 November 2015

\section{Keywords:}

Carbon cycle

Decomposition

Ectomycorrhizal fungi

Soil organic matter

Necromass

Nitrogen cycle

\begin{abstract}
A B S T R A C T
The turnover of ectomycorrhizal (EM) fungal biomass represents a significant input into forest carbon (C) and nutrient cycles. Given the size of these fluxes, understanding the factors that control the decomposition of this necromass will greatly improve understanding of $C$ and nutrient cycling in ecosystems. Recent research has highlighted the considerable variation in the decomposition rates of EM fungal necromass, and patterns from this research are beginning to emerge. In this article we review the research that has examined both intrinsic and extrinsic factors that control the decomposition of EM fungal necromass and propose additional factors that may strongly influence EM fungal necromass decomposition and ecosystem properties. We argue that, as with most plant litters, the stoichiometry (C:N) of EM necromass is an important factor governing decomposition, but its role is modulated by the nature of the $\mathrm{C}$ and $\mathrm{N}$ in the tissue. In particular, melanin concentration appears to negatively influence the quality of EM fungal necromass much as lignin does in plant litters. Other intrinsic factors such as the morphology of the mycelium may also play a large role and suggest this as a focus for future research. Extrinsic factors, such as decomposer community activity and physical protection by soil, are also likely to be important in governing the decomposition of ectomycorrhizal necromass in situ. Finally, we highlight the potential importance of EM fungal necromass diversity and abundance in influencing terrestrial biogeochemical cycles. Understanding the factors that control the decomposition of EM necromass will then improve the predictive power of next-generation terrestrial biosphere models.
\end{abstract}

() 2015 Elsevier Ltd. All rights reserved.

\section{Introduction}

Ectomycorrhizal (EM) fungi play a critical role in carbon (C) and nutrient cycling in many terrestrial ecosystems. The influence of EM fungi on nutrient uptake has been well documented, and its implications for ecosystem processes are now generally appreciated (Read, 1991; Read and Perez-Moreno 2003; Courty et al., 2010; Orwin et al., 2011). In addition, we are beginning to recognize the significance to biogeochemical cycles of inputs resulting from the death of EM fungal tissues (Fogel, 1980; Fogel and Hunt, 1983; Treseder and Allen, 2000; Langley and Hungate, 2003; Godbold et al., 2006; Cairney, 2012; Clemmenssen et al., 2013; Ekblad

\footnotetext{
* Corresponding author.

E-mail address: cwfernan@umn.edu (C.W. Fernandez).
}

et al., 2013). Until recently, little attention has been paid to EM fungal necromass inputs due to the fact that microbial necromass inputs have been considered to be relatively insignificant as standing pools of microbial biomass are often relatively small compared to those of standing plant biomass. However, due to the rapid turnover and replacement of microbial biomass, large quantities of $C$ and nutrients flow through the microbial pool, making its contribution to soil organic matter (SOM) disproportionately large relative to standing microbial biomass (Grandy and Neff, 2008). The turnover of microbial residues is now recognized as a major pathway to SOM formation (Kögel-Knabner, 2002; Cotrufo et al., 2013; Schmidt et al., 2011). For instance, efforts are underway to explicitly represent microbial pools as key components in the next generation of coupled biosphere-climate models (Todd-Brown et al., 2012; Wieder et al., 2013). 
Mycorrhizal fungi, in particular, appear to have great influence on C cycles in many terrestrial ecosystems (Read, 1991; Read and Perez-Moreno 2003; Godbold et al., 2006; Clemmensen et al., 2013; Averill et al., 2014; Clemmensen et al., 2015). Mycorrhizal fungi are unique among fungi in that the majority of their $\mathrm{C}$ is derived from living host plants (Hobbie et al., 2002). In terms of their $C$ source, these fungi are analogous to fine roots. While there is still some uncertainty associated with estimates of total $C$ allocation to EM fungi, evidence from multiple sites indicated that a considerable proportion of NPP is allocated belowground to these plant symbionts (Fig. 1). Using data from both lab and field studies, Hobbie (2006) found that $C$ allocation to EM fungi ranged from 1 to $22 \%$ of annual net primary productivity. Ekblad et al. (2013) suggested that approximately 7\% allocation of NPP to EM fungi is a reasonable estimate. More recently, Allen and Kitajima (2014) estimated that $27 \%$ of NPP allocated to EM fungi in a Californian mixed conifer-deciduous forest using minirhizotron techniques and 34\% of NPP using an isotopic fractionation model proposed by Hobbie and Hobbie (2006). In any case, the turnover of EM fungal biomass results in large inputs into $\mathrm{C}$ and nutrient cycles in terrestrial ecosystems (Fig. 1) (Godbold et al., 2006). Furthermore, the intimate association of the EM fungi with fine roots alters root biochemistry and decomposition, which is another large litter input (Langley and Hungate, 2003). Recently, Clemmensen et al. (2013) provided evidence suggesting that a very large portion (i.e. $>50 \%$ ) of $C$ stored in SOM in a boreal forest system was of fungal and root origin, supporting the hypothesis that belowground litter inputs are just as significant, if not more significant, than aboveground litter inputs into SOM pools in many ecosystems (Kätterer et al., 2011).

Given the large fluxes of $\mathrm{C}$ and nutrients entering the soil through fungal necromass and their substantial contribution to SOM, understanding the decomposition dynamics of these litter inputs has become an increasingly important line of research. In this review we focus on research that has examined the decomposition of EM fungal necromass with the goal of improving our understanding of the factors that control their decomposition. Specifically, we discuss the influence on the decomposition of EM fungal necromass of 1) chemistry, 2) the morphology of EM necromass, and 3) extrinsic factors (physical and physiochemical protection). We highlight the differences among EM species and the

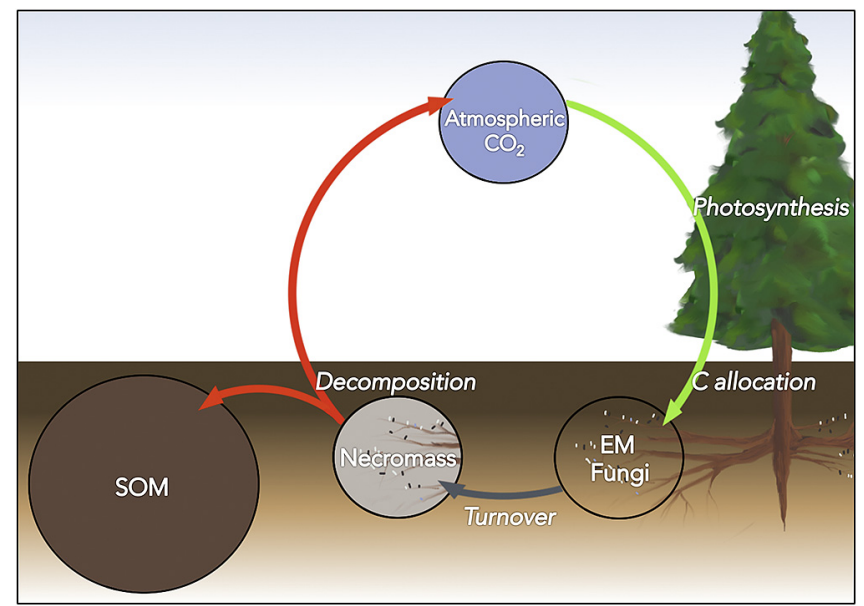

Fig. 1. A schematic diagram depicting the flow of carbon through the production (green), turnover (gray), and decomposition (red) of ectomycorrhizal (EM) fungal necromass into soil organic matter ( $\mathrm{SOM}$ ) and atmospheric $\mathrm{CO}_{2}$ pools. (For interpretation of the references to color in this figure legend, the reader is referred to the web version of this article.) potential for this variation to influence biogeochemical cycles and argue that EM fungal community structure will likely play a significant role in how these cycles are affected. Finally we discuss future directions within this burgeoning research area. It is important to recognize that other major types of mycorrhizal necromass, such as those produced by arbuscular and ericoid mycorrhizal fungi, may be equally important in contributing to stable SOM in other ecosystems (e.g. grasslands; tropical forest; bogs; heath). In our discussion of these topics we draw from the general fungal literature and therefore many of the concepts can be applied to understanding necromass decomposition dynamics of other groups of fungi. That said, we urge careful consideration of the sometimes-vast dissimilarities in traits and life histories among groups of fungi.

\section{How does biochemistry influence EM fungal necromass decomposition?}

\subsection{Necromass stoichiometry}

A major factor determining the decomposition of litter is the initial litter "quality" as determined by chemical composition (Melillo et al., 1982; Berg, 1984). Quality is a function of both the concentration of growth-limiting nutrients (i.e. C, N, P) and the recalcitrance, or the resistance to decomposition, of the molecules comprising the litter. Decomposition is generally favored by relatively low litter C:N ratios (Cleveland and Liptzin, 2007), which presumably helps to maintain the low C:N ratio of microbial cells (Sinsabaugh et al., 2009; Manzoni et al., 2010), yet, there is increasing evidence that additional aspects of quality beyond basic stoichiometry also can play a role determining decomposition rates.

Koide and Malcolm (2009) tested the role of C and N concentrations on the decomposition rate of EM fungal necromass in a litterbag study and found that initial $\mathrm{N}$ concentration was a good predictor of the decomposition rate of these tissues. However, Wilkinson et al. (2011) examined $\mathrm{CO}_{2}$ efflux from soil microcosms amended with the EM fungal necromass and found no relationship between the $\mathrm{C}$ and $\mathrm{N}$ contents or the $\mathrm{C}: \mathrm{N}$ ratio of the necromass with $\mathrm{CO}_{2}$ emitted during decomposition. Inconsistencies between these studies may be the result of differences between in situ and in vitro approaches. For instance, the decomposer communities used in microcosm experiments may exclude key functional groups (i.e. live EM fungi) that are found in natural conditions and may result in different decomposition dynamics. Additionally, there may be other key biochemical factors influencing the quality of the fungal necromass. Litters with high concentrations of recalcitrant compounds tend to have slower decomposition rates due to their resistance to enzymatic breakdown (Meentemeyer, 1978; Melillo et al., 1982). Lignin is a compound found in plant tissues that is, relative to many other compounds, quite resistant to decomposition due to its complex and irregular molecular structure. The decomposition of lignin requires the production of extracellular oxidative enzymes by decomposers (Kirk and Farrell, 1987). As a result, lignin:N ratios are often good predictors of aboveground litter and root litter decomposition rates (Melillo et al., 1982; Berg, 1984; Silver and Miya, 2001).

\subsection{Necromass chemical components}

Chemical composition varies widely among fungal species and likely contributes to the wide variation in decomposition rates of EM fungal necromass (Table 1). Indeed, components of the fungal cell may control the decomposition of EM fungal necromass. In contrast, the cytoplasmic fraction of fungal tissue does not likely play a significant role in the decomposition of EM necromass for 
Table 1

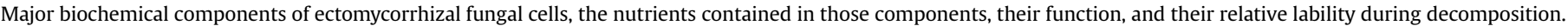
Uncertainties are denoted with a (?).

\begin{tabular}{|c|c|c|c|c|}
\hline Substrate & Nutrients & Component function & Enzymatic attack & Lability \\
\hline \multicolumn{5}{|l|}{ Cytoplasm } \\
\hline Solubles & $\mathrm{C}, \mathrm{N}, \mathrm{P}$ & Various & $\mathrm{N} / \mathrm{A}$ & High \\
\hline Glycogen & $\mathrm{C}$ & Energy storage & Hydrolytic & High \\
\hline Lipids & $\mathrm{C}$ & Energy storage \& Structural & Hydrolytic & High-Medium \\
\hline Protein & $\mathrm{C}, \mathrm{N}, \mathrm{P}$ & Various & Hydrolytic & Medium \\
\hline \multicolumn{5}{|l|}{ Cell Wall } \\
\hline \multicolumn{5}{|l|}{ Glucans } \\
\hline$\alpha$ - glucans & $\mathrm{C}$ & Matrix & Hydrolytic & High (?) \\
\hline$\beta$-glucans & C & Structural & Hydrolytic & Medium (?) \\
\hline Chitin & $C \& N$ & Structural & Hydrolytic & Medium \\
\hline \multicolumn{5}{|l|}{ Protein } \\
\hline Glycoproteins & $C \& N$ & Matrix, signaling & Hydrolytic & Medium (?) \\
\hline Hydrophobins & $C \& N$ & Water proofing & Hydrolytic(?) & Low (?) \\
\hline Melanin & $\mathrm{C}$ & Structural \& Protectant & Oxidative & Low \\
\hline
\end{tabular}

two reasons. First, in many cases little cytoplasm remains in senescing fungal tissues due to vacuolization accompanied by the movement of cytoplasm to vital regions of the mycelium (Saltarelli et al., 1998). Second, as with plant litters, the cytoplasmic fraction does not vary much in quality, is highly labile and appears to be rapidly taken up by decomposer organisms leaving mostly the cell wall fraction remaining (Nakas and Klein, 1979; Moucawi et al., 1981; Drigo et al., 2012). Therefore, it seems likely that the nature and composition of the cell wall fraction exerts the most control on the long-term decomposition of EM fungal necromass.

Approximately $20-50 \%$ of fungal biomass is found in the cell wall (Ruiz-Herrera, 1992). Once viewed as a static structure, the cell wall is now known to be a highly dynamic structure with its composition varying depending on factors such as age, genotype, taxon, and environment (Bartnicki-Garcia, 1968; Wessels, 1994; Bowman and Free, 2006; Feofilova, 2010). EM fungi, which are primarily members of the Basidiomycota and Ascomycota, have cell walls that are composed of $\beta$-glucans, chitin, proteins and melanins, along with other minor components (Wessels, 1994; Bowman and Free, 2006; Feofilova, 2010). There is wide variation in the decomposition rates of fungal cells among species (Hurst and Wagner, 1969) due to variation in the proportion of the cell wall comprising glucans, chitin, protein and melanin. Here, we provide an outline of the major components of the fungal cell wall that are likely to influence the decomposition of EM fungal necromass.

\subsubsection{Polysaccharides: glucans and chitin}

The majority of the fungal cell wall is composed of polysaccharides, which account for approximately $80-90 \%$ of the cell wall dry mass for most species (Bartnicki-Garcia, 1968). The cell walls of Basidiomycete and Ascomycete fungi are then anchored with carbohydrate microfibrils, composed of cross linked $\beta-(1-3)$, $\beta-(1,4)$ and $\beta-(1,6)$-glucans and chitin suspended in a matrix of various glycoproteins and amorphous $\alpha$-(1,3)-glucans (Feofilova, 2010). Glucans are polysaccharides composed of glucose monomers bound with either $\alpha$ - or $\beta$-bonds at different $C$ units on the glucose monomer. Though glucans are major components of fungal cell walls (Table 1 ), the role they play in decomposition of EM fungal necromass is not clear. However, because glucans are structurally similar to cellulose, and because similar extracellular enzymes are employed by decomposers to depolymerize them, it is reasonable to expect that their decomposition rates would be similar. Like cellulose in plants, $\beta$-glucans interact with other cell wall components such as chitin or melanin, which may alter the chemical properties and as consequence the chemical recalcitrance of the substrate (Treseder and Lennon, 2015). Finally, some $\beta$-glucans can increase the water holding capacity of the cell wall
(Kyanko et al., 2013), which may indirectly increase the decomposability of the necromass when water availability is a limiting factor.

Chitin is one of the most common polymers found on earth, with conservative estimates ranging from approximately $0.09 \mathrm{Pg}$ to 0.9 Pg produced by fungi and arthropods annually (Gooday, 1995), which accounts for approximately $0.04 \mathrm{Pg}$ to $0.40 \mathrm{Pg}$ of $\mathrm{C}$ and $6.2 \mathrm{Tg}$ to $62 \mathrm{Tg}$ of $\mathrm{N}$ globally. Chitin is composed of n-acetylglucosamine monomers with $\beta-(1,4)$ linkages and represents a significant source of $\mathrm{C}$ and $\mathrm{N}$ in many ecosystems. Concentrations of chitin as high as $20-30 \%$ of dry weight have been found in some filamentous fungi (Bowman and Free, 2006), but chitin concentrations in EM fungi typically range from 1 to $10 \%$ of dry weight (Ekblad et al., 1998; Markkola et al., 2002; Fernandez and Koide, 2012).

In recent years there has been some confusion surrounding the decomposition of the polysaccharide fraction of fungal cell walls, particularly chitin. Early work examining the decomposition of pure chitin in soil microcosms showed that pure chitin is decomposed more rapidly than pure cellulose when added to soil (Trofymow et al., 1983). However, more recently ecologists have suggested that chitin is a recalcitrant polymer in fungal necromass and may result in a large build up of fungal necromass in soil organic matter (SOM) (Treseder and Allen, 2000; Langley and Hungate, 2003; Godbold et al., 2006). One of the problems with decomposition studies is that recalcitrance is not explicitly defined in many cases (see Schmidt et al., 2011). Fernandez and Koide (2012) explicitly examined the recalcitrance of chitin relative to all other fungal cell components by measuring changes in chitin concentration over the course of decomposition of EM fungal necromass. For all the EM fungi isolates that were tested, a rapid decline in chitin concentration was found, suggesting that chitin was preferentially decomposed relative to other cell wall components. In addition, initial chitin concentrations were positively related to percent mass loss of the necromass. Supporting these findings, Drigo et al. (2012), used a microcosm experiment designed to examine the decay of cell wall components of the EM fungus Pisolithus microcarpus utilizing stable isotope probing methods. They found a rapid decline (within 10 days of addition) in the chemical functional groups associated with the glucan-chitin complex. Zeglin et al. (2013) reported rapid assimilation of pure chitin and $\mathrm{N}$-acetylglucosamine monomers into microbial biomass when added to soil microcosms containing fungal-mat communities from old-growth Douglas-fir forest. Similarly, Russell (2014) found rapid decomposition of chitin amendments to wet tropical forest soil. Both fungi and bacteria produce a variety of extracellular enzymes, classified as chitinases (e.g. NAGase), that hydrolyze the glycosidic bonds of chitin into simpler molecules making them 
available for uptake (Gray and Baxby, 1968). Furthermore, because chitin is a N-rich compound, its rapid degradation and incorporation may be driven by $\mathrm{N}$ limitations of decomposer fungi and bacteria (Fernandez and Koide, 2012). However, rapid degradation of chitin has also been found in relatively N-rich soils where decomposers were not likely limited by N (Russell, 2014). Taken together, these findings suggest that chitin, itself, is not resistant to decomposition relative to other compounds in fungal necromass, and may be an important source of both $\mathrm{C}$ and $\mathrm{N}$ to soil decomposer communities.

\subsubsection{Proteins}

While only a minor component (Table 1 ) relative to polysaccharides, the proteins found in fungal cell walls vary greatly in function, chemistry, and potential influence on decomposition dynamics of EM fungal necromass. Proteins are composed of amino acids that are linked with peptide bonds. Fungal cell protein concentrations can vary widely among fungal species (Christias et al., 1975). Despite being a relatively minor component (ca. $15-30 \%$ dry mass) in total biomass, approximately $60-70 \%$ of $\mathrm{N}$ in fungal cell walls occurs in proteins owing to their high $\mathrm{N}$ concentrations (Bowman and Free, 2006; Smiderle et al., 2012), mostly as glycoproteins, which have both structural and signaling functions (Bowman and Free, 2006). Proteins are generally thought to decompose rapidly (Kögel-Knabner, 2002), a result of proteins being hydrolysable compounds that are rich in growth-limiting $\mathrm{N}$. However, glomalin-related soil proteins, a class of glycoprotein produced by arbuscular mycorrhizal (AM) fungi, is resistant to decomposition (Steinberg and Rillig, 2003) and may be involved in the stabilization of soil aggregates (Rillig, 2004). Glomalin-related soil proteins may be resistant to decomposition because of its hydrophobic nature (Rillig and Mummey, 2006). It is unclear if EM fungi synthesize similar glycoproteins that are similarly resistant to degradation, but hydrophobins (cysteine-rich hydrophobic proteins) produced by Basidiomycetes and Ascomycetes (Wessels, 1996; Wösten and de Vocht, 2000; Rillig et al., 2007) may be similarly resistant to decomposition. These proteins are arranged as a film on the outside of the cell wall, making it unwettable (Wösten and de Vocht, 2000). The unwettable nature of these tissues is likely to then impede their enzymatic decomposition (Rillig et al., 2007). Hydrophobins are also important in the formation of ectomycorrhizas and play a role in the retention and transportation of water in the extramatrical mycelium (Unestam and Sun, 1995).

\subsubsection{Melanin}

Melanins are complex, dark biopolymers that are produced by animals, bacteria and fungi. While the chemical structure of these compounds is poorly understood, they are known to be generally composed of phenolic and indolic monomers (Bull, 1970; Bell and Wheeler, 1986; Butler and Day, 1998a). Fungi produce four classes of melanin that vary in their precursors and biosynthetic pathways. These include $\gamma$-glutaminyl-3,4-dihydroxybenzene (GDHB) melanin, dihydroxyphenylalanine (DOPA) melanin, dihydroxynaphthalene (DHN) melanin and catechol melanin (Butler and Day, 1998a). Melanin type appears to be largely determined by phylogeny; Basidiomycetes produce GDHB and DOPA melanins, while Ascomycetes produce primarily DHN melanin but may also produce DOPA and catechol melanins (Bell and Wheeler, 1986; Butler and Day, 1998a). The production of melanin in fungi has been linked to the tolerance of various environmental stressors, including high temperature (Rosas and Casadevall, 1997), water stress (Rehnstrom and Free, 1996; Kogej et al., 2007; Fernandez and Koide, 2013; Kejžar et al., 2013), ultraviolet light (Wang and Casadevall, 1994). Melanin content also varies tremendously across taxa, with some fungi being completely hyaline (low melanin) and others heavily melanized (Hurst and Wagner, 1969; Butler and Day, 1998a, Table 1.). As with lignin, melanins lack stereo-specific binding sites, which hydrolytic enzymes target, making these compounds unhydrolyzable (Butler and Day, 1998b). Two early studies using ${ }^{14} \mathrm{C}$ labeled fungal material amendments to soil microcosms examined the potential recalcitrance of melanin. Hurst and Wagner (1969) contrasted the mineralization of cell wall amendments from melanized and hyaline fungi and found that the cell walls from melanized fungi were mineralized relatively slowly when compared to those from hyaline fungi. These findings were later supported in a study by Malik and Haider (1982), who found that melanin fractions of fungal cells were mineralized at a slower rate than total cell wall and cytoplasm fractions in all fungal isolates tested.

Cenococcum geophilum, one of the most abundant and ubiquitous EM fungal species globally, produces a large amount of melanin in its cell walls (Pigott, 1982). Fernandez et al. (2013) demonstrated with minirhizotron imaging and vital staining that the ectomycorrhizas of $C$. geophilum were 4-10 times more persistent than ectomycorrhizas of other species, suggesting that their decomposition was significantly lower. The persistence of structures in soil can be the result of increased lifespan as oppose to resistance to decomposition. However, vitality staining of ectomycorrhizas revealed that a large proportion of $C$. geophilum ectomycorrhizas sampled were not metabolically active suggesting that longer persistence times associated with these ectomycorrhizas were likely the result of their resistance to decomposition. Later, Fernandez and Koide (2014) measured the decomposition rates of EM fungal necromass that varied in melanin concentration and found that there was a significant negative relationship between melanin concentration and decomposition rate. This finding was supported with a second, manipulative experiment in which melanin biosynthesis of $C$. geophilum isolates was inhibited with the melanin inhibitor, tricyclazole. Again, there was a negative relationship between melanin content and decomposition rate. Together these studies show that melanin itself is resistant to decomposition and reduces the overall decomposability of the fungal tissues in which it is found. Recently, Clemmensen et al. (2015) also provided support for the hypothesis that melanization contributes to the stabilization of fungal $C$ in soil by showing significant correlations between the abundance of melanized fungi and $\mathrm{C}$ accumulation in SOM.

The relative recalcitrance of melanins is likely a result of the complex aromatic nature of these polymers that require oxidative enzymes to degrade. While Butler and Day (1998b) found that peroxidases produced by a lignin decomposer fungus effectively degraded fungal melanin, melanin has also been shown to inhibit common enzymes used to decompose other cell wall components including chitin and $\beta$-glucan (Kuo and Alexander, 1967). Thus, melanin may influence the overall decomposability of the fungal necromass by affecting the decomposition of other components. Because of its recalcitrance, its requirement for oxidative enzymes for degradation, and the large variation in concentrations across fungal species, melanin in fungal tissues may be analogous to lignin in plant tissues in biochemical control of necromass decomposition. Additionally, melanized hyphae also have higher sorption to soil mineral components compared to hyaline hyphae (Fomina and Gadd, 2003), which may result in physiochemical protection of necromass $C$, which would also result in increased incorporation into stable SOM (Fernandez and Kennedy, 2015).

\subsubsection{Other secondary compounds}

Fungi produce a myriad of other secondary compounds that likely influence the decomposition of their tissues (Keller et al., 2005). These compounds can range widely in function but a large 
proportion appear to be involved in inhibiting the growth of bacteria and other fungi (Keller et al., 2005). A major area of research in mycorrhizal ecology is the role of EM fungi in protecting plants from root pathogens (Marx, 1972; Fitter and Garbaye, 1994; Nagy and Fossdal, 2013). EM fungi have been shown in numerous studies to ward off fungal and bacterial root pathogens using secondary compounds. Garrido et al. (1982) surveyed the antimicrobial properties of 36 fungi in the Agaricales (including both EM and saprotrophic species) and found that the extracts of the vast majority of these isolates inhibited the growth of one or more bacterial strains. Antibiotic activity has also been found in isolates of C. geophilum (Krywolap and Casida, 1964). If these antibiotic compounds persist near or within the EM tissues after the death of EM tissues they have the potential to inhibit the decomposition of the resulting necromass. Currently, we do not know of any study explicitly examining antibiotic compounds on necromass decomposition but represents an intriguing line of research.

In addition to antibiotic compounds, fungi produce a wide array of volatile organic compounds (VOCs) that can have negative effects on competing fungi. Common EM fungal taxa often produce these compounds in large quantities (Krupa and Fries, 1971) and may reduce the effectiveness of decomposer organisms by directly inhibiting their growth near the EM fungal mycelium. The most well-known example of this phenomenon occurs in soil where truffle-producing EM fungi in the genus Tuber are dominant. These fungi produce large quantities of VOCs that reduce the surrounding plant diversity by creating bare soil patches known as brûlés (French for "burnt"). The VOCs produced by Tuber sp. also drastically influence the microbial communities in these soils. Napoli et al. (2010) showed that fungal communities within brûlé soil were dominated by Tuber melanosporum and had significantly lower species richness compared to soil outside of brûlés. Basidiomycetes, in particular, declined in diversity. This drastic effect on fungal communities likely influences the biogeochemical cycling in these soils and may negatively impact litter decomposition and potentially increase contribution of necromass to SOM. The residence time of these compounds in soil is probably an important factor in determining how much influence they have on the decomposition of EM fungal necromass. However, given the clumped spatial distribution of some EM fungi (Lilleskov et al., 2004; Pickles et al., 2010) it is not hard to imagine patches of living mycelium producing antibiotic compounds or VOCs that slow the decomposition of adjacent EM necromass by making the surrounding soil toxic to decomposers. Ultimately, the effects of these compounds on the decomposition of EM fungi have yet to be explicitly examined.

The production of acids by EM fungi has been shown to have antagonistic effects on other microorganisms via the reduction of pH (Rasanayagam and Jefferies 1992), which may indirectly reduce decomposition rates of EM fungal necromass by reducing the habitat suitability of the surrounding soil for decomposer microbes. Some EM fungi produce large amounts of oxalic acid, which reduces the $\mathrm{pH}$ of the surrounding soil and chelates calcium ions, increasing the availability of nutrients such as phosphorus and sulfur. As a result, these fungi accumulate a great deal of oxalate crystals on and around their hyphae, which may slow the decomposition of necromass with heavy deposition of oxalate (Cromack et al., 1977). Some bacteria and soil fauna may, however, specialize on the consumption of oxalate crystals as they may be sources of calcium (Cromack et al., 1977) and potentially may increase the decomposability of associated EM fungal necromass. Crowther et al. (2015) examined the effects of abiotic (water stress) and biotic (fungal grazers) stressors had on the stabilization of fungal $C$ in SOM fractions from two cord-forming wood saprotrophs. Both water stress and grazing lead to increased production of calcium oxalate crystals in both fungal species, which lead to subsequent decreases in C stabilization. Recently, Keiluweit et al. (2015) have provided evidence that suggests that oxalic acid is involved in stimulating microbial carbon mineralization through liberating organic compounds from protective associations with soil minerals (further discussed in Section 5.2). Thus, necromass that has heavy accumulation of oxalate crystals may effectively reduce mineral sorption leading to stimulated decomposition.

\section{What effect does mycelial morphology have on ectomycorrhizal fungal necromass decomposition?}

EM fungi exhibit a large degree of variation in the anatomy of hyphae, which can vary in cell wall thickness, branching, and cell diameter (Rillig and Mummey, 2006). This variation is compounded by the numerous mycelial morphologies produced by fungi. Most fungi will produce a diffuse mycelium when grown in culture in which resources are homogeneously distributed. Thus, the research examining the decomposition of fungal tissues has been biased towards lab-grown diffuse mycelium (see Koide and Malcolm, 2009; Koide et al., 2011; Wilkinson et al., 2011; Drigo et al., 2012; Fernandez and Koide, 2012). However, the physiochemical properties of hyphae are often dependent on the structures that are constructed in response to the natural environment. The physiochemical properties of hyphae, in turn, influence the decomposition of the resulting necromass. EM fungi allocate a great deal of resources to produce specialized structures that carry out certain functions in the life cycle of the fungus such as host resource exchange and interaction (ectomycorrhizas), soil resource acquisition (cords, rhizomorphs, hyphal mats), reproduction and dispersal (sporocarps), and dormancy (sclerotia) (Fig. 2), each of which may then have unique properties related to necromass decomposition.

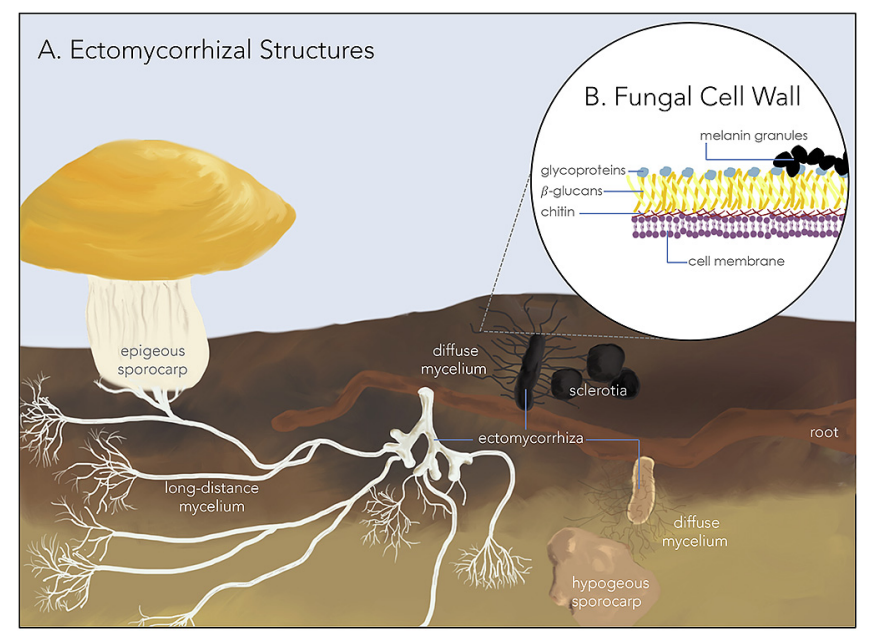

Fig. 2. A. Diagram illustrating the types of ectomycorrhizal fungal necromass resulting from the turnover of ectomycorrhizal fungal structures. Mycelium color (i.e. white brown, black) represents tissues produced by different ectomycorrhizal fungal species. The ectomycorrhiza is a composite organ consisting of both fungal and plant tissues. The physiochemical properties of the ectomycorrhiza can vary dramatically among ectomycorrhizal fungal species. Extending from the ectomycorrhiza is the extramatrical mycelium which explores the soil for resources. The extramatrical mycelium varies widely in morphology and length among ectomycorrhizal fungi but can be coarsely grouped as simple diffuse or long-distance mycelium (rhizomorphs; cords). Finally ectomycorrhizal fungi produce epigeous sporocarps or hypogeous sporocarps while others produce resting structures called sclerotia. B. A generalized schematic of the common components of fungal cell walls. (For interpretation of the references to color in this figure legend, the reader is referred to the web version of this article.) 


\subsection{The ectomycorrhiza}

The ectomycorrhiza is a composite structure comprising both fungal and plant tissues. Because of the intimate association, the fungus significantly alters the chemistry of the root. Therefore, root decomposition is influenced by mycorrhizal colonization (Langley et al., 2006). Fine-root production represents a large annual $C$ input into forest ecosystems, accounting for approximately onequarter of global annual NPP (McCormack et al., 2015). Langley and Hungate (2003) highlighted the potential influence of EM fungal colonization on the decomposition of fine roots, hypothesizing that EM colonization would reduce the decomposition rate of fine roots. Later, Langley et al. (2006) found support for this hypothesis in an experiment comparing decomposition rates of nonmycorrhizal fine roots and EM fine roots of pinyon pine (Pinus edulis). With the goal of understanding potential species differences, Koide et al. (2011) examined the effects of colonization of different EM fungal species on the decomposition of red pine (Pinus resinosa) fine roots. Of the ectomycorrhizas examined in this study, only ectomycorrhizas from a Suillus sp. had significantly different decomposition rates from non-mycorrhizal fine roots, which actually decomposed faster than non-mycorrhizal fine roots. In a minirhizotron study, Fernandez et al. (2013) observed that ectomycorrhizas of $C$. geophilum persisted in the soil 4-10 times longer than other ectomycorrhizas of other species likely due to reduced decomposition rates from highly melanized tissues. Interestingly, the P. edulis site studied by Langley et al. (2006) is dominated by a single EM fungus, Geopora sp., that happens to be highly melanized (C. Gehring; Personal Communication) unlike the hyaline ectomycorrhizas examined in Koide et al. (2011), which may explain some of the discrepancy between the two studies. Together, these studies highlight the importance of fungal species identity to determine the effect of colonization on fine-root decomposition.

\subsection{Rhizomorphs, cords, and mats}

Ectomycorrhizal fungi vary widely in their morphology and physiochemical properties. We argue that these differences in morphology of extramatrical mycelium might lead to variation in decomposition. For instance, long distance exploration structures of EM fungi are often hydrophobic (Agerer, 2001) and thus likely to be more resistant to decay than EM fungi with shorter exploration strategies that are often hydrophilic. Some Basidiomycete EM fungi produce structures thought to be important for efficient resource foraging across relatively long distances in the soil. Rhizomorphs are tube-like structures of linearly aligned hyphae differentiated into a medulla, composed of large diameter hyphae, upwards of $25 \mu \mathrm{m}$, encased by a cortex of smaller diameter, hydrophobic hyphae (Cairney et al., 1989). These structures grow apically and are able to conduct water and nutrients across meters of soil (Brownlee et al., 1983), which can be of particular advantage when resources are distributed heterogeneously. While similar in function, fungal cords are constructed from simple diffuse mycelium that subsequently aggregates after some time to form cord like structures. Rhizomorphs and cord structures may persist for months to years, indicating a possible resistance to decomposition (Treseder et al., 2005; Pritchard et al., 2008; McCormack et al., 2010). The resistance may be due to the hydrophobic surfaces, as well as the relatively low surface area-tovolume ratio compared to undifferentiated or diffuse hyphae. Interestingly, McCormack et al. (2010) found that larger diameter rhizomorphs had shorter persistence times than those with smaller diameters which is counterintuitive because smaller diameters would lead to more surface area exposed to decomposers and increased decomposition rates. These longer persistence times of the smaller diameter rhizomorphs could be the result of differences in lifespan and/or dormancy of these structures among functionally different species, which could not be identified in the study. In addition, the effective surface area of the larger diameter rhizomorphs could be greater if they have a large lumen, which would expose more internal tissue to decomposers and accelerate decomposition. Alternatively, Clemmensen et al. (2015) have suggested that rhizomorphic and cord-forming EM fungi may be efficient recyclers of their biomass and able to translocate resources to new growth. Recycling of biomass would thus reduce persistence times of these structures and potentially complicate the interpretation of minirhizotron data. In any case, because rhizomorphic strategies are common among EM fungi, future studies should be directed to better understand the factors that lead to the sometimes long, yet variable persistence of rhizomorphs and cords.

Ectomycorrhizal fungi can also form dense hyphal mats, which can account for ca. $50 \%$ of the dry mass of the organic layer in some forest soils (Griffiths et al., 1990). These fungal mats are common globally but are particularly well-studied in boreal forest systems dominated by Douglas fir species (Psuedotsuga sp.) (Griffiths et al., 1990, 1996). Fungal mats can be rhizomorphic and extremely hydrophobic depending on the species involved (Unestam and Sun, 1995). The community composition of mat soils was once thought to be dominated by single species of EM fungi but there is now evidence provided by molecular analyses that these communities are more diverse and may be formed by over 20 EM species (Dunham et al., 2007). Because of the large amount of aggregated biomass, EM fungal mats significantly alter the biogeochemistry of the area they inhabit (Kluber et al., 2010). The decomposition of these mat structures remain unexamined but are likely influenced by many of the chemical properties discussed above as well as unique physical aspects of the mat structures themselves.

\subsection{Sporocarps and sclerotia}

Perhaps the most underappreciated, yet most visible, EM fungal necromass results from sporocarp production. A great deal of $C$ and $\mathrm{N}$ is allocated to the production of these structures in many EM fungal species (Vogt and Edmonds, 1980). The production of sporocarps is highly variable across species, time and ecosystems. Dahlberg et al. (1997) found the average sporocarp production in a spruce forest in southern Sweden to be $8.8 \mathrm{~kg} \mathrm{ha}^{-1} \mathrm{yr}^{-1}$, while Vogt et al. (1981) found levels of sporocarp production between 27 and $380 \mathrm{~kg} \mathrm{ha}^{-1} \mathrm{yr}^{-1}$ (dry weight) in spruce stands in western Washington, USA. The functional specialization of sporocarps is reflected in their chemistry. Protein and chitin concentrations of these structures are significantly different from the associated belowground mycelium; sporocarps are usually enriched in protein and depleted in chitin (Taylor et al., 1997). Thus, these structures may have different decomposition dynamics from the associated belowground mycelium, however this is pure speculation and to our knowledge these comparisons have not yet been made.

Some EM fungi also produce sclerotia, essentially hardened resting structures composed of mycelia that can remain viable in the soil for at least 2 years (Miller et al., 1994). Cenococcum geophilum can produce sclerotia in great quantities, which may then build up to levels estimated to be as high as $3000 \mathrm{~kg} \mathrm{ha}^{-1}$ in some ecosystems (Vogt et al., 1981). Considering the extremely slow decomposition rate of structures produced by the heavily melanized Cenococcum geophilum, including ectomycorrhizas and sclerotia, may represent a large and incredibly stable $C$ input into forest ecosystems (Watanabe et al., 2007). Many EM fungi have been shown to produce sclerotia with considerable variation in morphological traits across taxa (Smith et al., 2015), which 
warrants further consideration and investigation into the production, turnover, and decomposition of these structures and the subsequent effects on forest $\mathrm{C}$ cycling.

\section{Appreciating the diversity of ectomycorrhizal fungal necromass}

Ectomycorrhizal fungal communities are often highly diverse, with species richness exceeding 100 in some ecosystems (Dickie, 2007). Given the variation in decomposability of EM fungal tissues, an understanding of the effects of mycorrhizal fungi on $\mathrm{C}$ and nutrient cycling therefore requires an understanding of fungal diversity. The importance of species differences in decomposition dynamics should not be underestimated for EM fungal necromass. Species of EM fungi span two Phlya: Basidiomycota and Ascomycota. As demonstrated above, differences in chemical and physical properties between two relatively related species can be quite large and lead to very different decomposition rates. Because a single tree may host dozens of EM fungal species, its fine roots (ectomycorrhizas) can then express different decomposition rates as a result and may have profound effects on $\mathrm{C}$ and nutrient cycling. Additionally, in a community with low species evenness, a single species could exert considerable control on $\mathrm{C}$ and nutrient cycling. For instance, $C$. geophilum is often abundant in communities (i.e. up to $97 \%$ relative abundance was found in a Quercus rubra stand; Trocha et al., 2012) and so may result in more $C$ sequestered in organic matter than some other species (Fernandez et al., 2013).

Much of the discrepancies in either the decomposition rates or contribution to SOM of fungal necromass between studies may be the result of species differences. Throckmorton et al. (2012) examined differences between fungal and bacterial contributions to SOM by measuring the retention of ${ }^{13} \mathrm{C}$-labeled necromass in soils of temperate and tropical forest ecosystems. They found no differences in mean residence times of $\mathrm{C}$ in soil contributed by fungi and bacteria. Also, fungi from the two sites (California and Puerto Rico) did not differ in their decomposition, leading the authors to conclude that site differences were more important than species identity of the fungal necromass in terms of retention of $C$ in SOM. However, the range of species used was limited to 4 from each site and both amendments were dominated (78\% and $87 \%$ of the biomass) by a single genus (Penicillium). Given the wide variation in decomposability of fungal tissues, additional studies with greater levels of diversity would be helpful in understanding the contribution to SOM by fungal necromass.

In addition to the effects of fungal community structure on decomposition, there are other potential interactive effects that necromass from different fungal species may have on ecosystem processes. Litter mixtures can exhibit non-additive effects on decomposition, resulting in faster or slower rates than expected (Wardle et al., 2003; Gartner and Cardon, 2004; Chapman and Koch, 2007; Jonsson and Wardle, 2008). This interactive effect can arise from synergies among the chemical (Talbot and Treseder, 2012) or physical (Makkonen et al., 2012) properties of litters and the decomposer community (Chapman et al., 2013). Using multiple sites across different ecosystems, Handa et al. (2014) demonstrated that decreasing plant litter diversity slows decomposition, and as consequence, $\mathrm{C}$ and $\mathrm{N}$ cycling were retarded. Given the close proximity of EM fungal hyphae to other litter types (e.g. roots, leaf litter in organic horizons), there are likely to be interactions between the fungi and the other litters during decomposition. Poorer quality litter may decompose at an unexpectedly high rate due to priming provided by nearby higher quality litter, which may allow for increased production of extracellular enzymes for degrading the relatively recalcitrant compounds (Talbot and Treseder, 2012). In a microcosm study Wilkinson et al. (2011) examined the effects of EM fungal necromass mixtures on decomposition rates and found non-additive effects of increasing necromass diversity on $\mathrm{CO}_{2}$ efflux. For instance, the necromass of Amanita muscaria and Paxillus involutus had higher $\mathrm{CO}_{2}$ efflux values when mixed than when decomposed alone. In contrast, Cenococcum geophilum and Hebeloma crustuliniforme necromass produced higher $\mathrm{CO}_{2}$ effluxes when alone than when mixed.

\section{Extrinsic factors}

\subsection{Physical and spatial protection}

Relatively labile compounds can persist in SOM for long periods as a consequence of physical protection either through soil aggregation or sorption (Nelson et al., 1979; Six et al., 2006; Grandy and Robertson, 2007; Grandy and Neff, 2008). Fungal hyphae have intimate physical and chemical interactions with soil structures, which can lead to stabilization and protection of organic compounds in soils (Tisdall, 1994; Rillig et al., 2015). Thus, variation in the chemistry of hyphal cell walls, the morphology of the extramatrical mycelium and the production of extracellular compounds could alter the degree of physical protection of EM necromass. Bogeat-Triboulot et al. (2004) found that fine roots colonized by Hebeloma cylindrosporum had higher soil adhesion compared to those formed by Lactarius bicolor and Telephora terrestris. Recently, Zheng et al. (2014) compared the effects of 9 EM fungal isolates on soil aggregation and soil water repellency in a microcosm study and found a significant amount of variation across the isolates. It is unclear what traits are responsible for differential effects on aggregate formation and stabilization, but they may be the result of differences in cell wall components (i.e. glycoproteins and hydrophobins as discussed above in Section 2.2.2), exudation, and/or differences in mycelium morphology (i.e. diffuse vs. rhizomorphic). It stands to reason that cords and rhizomorphs are less likely to be protected in this manner because of their relatively large diameter though their hydrophobicity may have the potential to alter smallscale movement of water, which could reduce decomposition. Additionally, fine roots, which are of similar size are important in macroaggregate formation and stabilization so it may also be reasonable for rhizomorphs to serve a similar function.

EM fungi inhabit distinct vertical niches in soil, a likely consequence of resource niche partitioning (Dickie et al., 2002; Rosling et al., 2003). It is thought that EM fungi positioned higher in the profile rely more on recent aboveground litters containing more labile compounds, while EM fungi found deeper in the soil profile specialize on breaking down more recalcitrant compounds (Lindahl et al., 2007; Talbot et al., 2013). Position in the soil profile also dictates decomposer community structure as well as temperature, moisture, and other physical soil properties (Schmidt et al., 2011). Unlike aboveground litters, EM fungal necromass is produced and deposited at different positions in the soil profile. Thus, there is potential for a species' litter decomposition to be controlled largely by location in the soil profile. For example, there are slower turnover and decomposition rates of root litter at deeper depths in the soil profile (Gill and Burke, 2002; Joslin et al., 2006; McCormack et al., 2010). Recently, Schweigert et al. (2015) traced the fate of ${ }^{13}$ C-labeled Laccaria bicolor biomass amendments in an in vitro soil bioreactor experiment. They found that a significant proportion of the ${ }^{13} \mathrm{C}$ (52\%) remained undecomposed in the form of stable SOM after $231 \mathrm{~d}$. This is in contrast to prior studies that generally have found rapid decomposition of hyaline necromass (Koide and Malcolm, 2009; Wilkinson et al., 2011; Drigo et al., 2012; Fernandez and Koide, 2012). This discrepancy may be due to the fact that Schweigert et al. (2015) used only mineral soil and perhaps 
had higher protected fungal $\mathrm{C}$ via sorption to soil structures (see discussion below) while previous studies used amended organic layers (Koide and Malcolm, 2009; Drigo et al., 2012; Fernandez and Koide, 2012).

Because we see clear vertical niche patterns for many EM fungal species, there may be interesting interactions between necromass quality and factors related to soil profile (Fernandez and Kennedy, 2015). For instance, an EM fungal species can produce necromass of high quality, but the naturally rapid decomposition rate of that necromass may be counteracted by its occurrence in lower soil profiles. Depending on if sporocarps are epigeous (aboveground) or hypogeous (belowground) may also influence the rate at which they are decomposed. Finally, for some species that produce a relatively large number of sporocarps (Kikuchi and Futai, 2003), we may see a considerable amount of $C$ and nutrients move aboveground from the mycelium belowground where it would presumably decompose at a faster rate. However, this may not necessarily hold true for spores produced by these structures, particularly those that are relatively persistent in the soil (Nguyen et al., 2012)

\subsection{Decomposer communities and extracellular enzyme production}

Once viewed as homogenous and functionally redundant, variation in the structure of soil microbial communities is now recognized as a major factor determining litter decomposition rates in soils (Zak et al., 1994; Strickland et al., 2009a,b). Our understanding of the decomposer communities that are responsible for the degradation of fungal necromass is poor when compared to that of plant litter. In particular, it remains uncertain whether microbes that specialize in decomposing fungal necromass are common in forest soils or if decomposition of fungal necromass is primarily carried out by generalist decomposers. Many of the substrates found in EM fungal necromass are degraded with extracellular enzymes that degrade substrates found in plant litter so specialization may be rare. For instance, some $\beta$-glucans share a similar chemical structure with cellulose and can be hydrolyzed with cellulase enzymes (e.g. $\beta$-glucosidase). Similarly, fungal melanins are degraded with the same oxidative enzymes involved in lignin decomposition (e.g. peroxidase), which are non-specific to substrate. Finally, proteins, regardless of origin, are hydrolyzed by protease enzymes (e.g. endoprotease; aminopeptidase). Chitin, however, is found only in fungal and arthropod tissues and is hydrolyzed with chitinases (e.g. endo-chitinase, N-acetylgucosaminidase). Early work by Gray and Baxby (1968) found that the ability of decomposer fungi and bacteria to utilize chitin as a substrate was common, but some taxa appeared to be more proficient than others. Presumably soils high in EM fungal necromass production have microbial decomposer communities specializing in the degradation of chitin and other fungal compounds. For example, in EM fungal mat communities, in which soils have large quantities of standing fungal biomass, chitin and N-acetyl-glucosamine (NAG) are cycled quickly compared to soils where mat-forming EM fungi are absent (Zeglin et al., 2013), perhaps due to decomposer communities specializing on EM fungal necromass in mat soils (Kluber et al., 2011). DNA-stable isotope probing (SIP) techniques coupled to molecular methods and bioinformatics might be an approach that will allow us to trace $\mathrm{C}$ and $\mathrm{N}$ that is found in EM fungal necromass into decomposer pools (Drigo et al., 2012). The extent to which $C$ and nutrients in EM fungal necromass are recycled by live EM fungi is not clear but this represents a potentially significant line of future research, as this would reduce the amount of $C$ entering both the decomposer and SOM pools (Kerley and Read, 1998; Lindahl et al., 2002; Clemmensen et al., 2015).

Extracellular enzyme activity is often linked to resource limitations in the soil (Burns, 1982; Sinsabaugh et al., 2002) and because EM fungal necromass are N-rich, substrates from these litters are likely to be in high demand under N-limited conditions. Inorganic $\mathrm{N}$ deposition alters decomposer (and EM fungal) communities and their enzymatic activity, which may have implications for the decomposition of EM fungal necromass. For instance, elevated concentrations of atmospheric $\mathrm{CO}_{2}$ in a loblolly pine forest were associated with increased NAGase activity, yet these increases were canceled out by N fertilization (Meier et al., 2015). More generally, depressions in NAGase activity have been associated with increased N availability (Olander and Vitousek, 2000), although this is not true in every ecosystem (Waldrop et al., 2004). Shifts away from oxidative to increased hydrolytic extracellular enzyme production have also been associated with elevated $\mathrm{N}$ deposition (Carreiro et al., 2000; Sinsabaugh et al., 2002; Frey et al., 2004). Because melanin is not hydrolysable and requires oxidative enzymes for its breakdown, we may then expect melanin decomposition to decline with elevated $\mathrm{N}$, much like what has been found with lignin.

Climatic factors such as temperature and precipitation strongly influence the decomposition rates of litters (Aerts, 1997), and the effects of climate on litter decomposition and generation of SOM are of great interest in the light of climate change. Because the decomposition process is more sensitive to temperature shifts than primary productivity there is concern of positive feedbacks amplifying climatic warming (Davidson and Janssens, 2006). Generally speaking, the decomposition rate of litter increases with temperature. However, enzymes involved in the breakdown of complex, recalcitrant $C$ substrates appear to be more sensitive to temperature than those involved in breakdown of labile substrates (O'Connell, 1990; Hobbie, 1996; Fierer et al., 2005). This sensitivity is due to the enzyme kinetics; more complex substrates require higher activation energies than less complex substrates (Fierer et al., 2005). It therefore stands to reason that the decomposition rates of chemically recalcitrant EM necromass would have similar temperature sensitivity to recalcitrant plant litters, but that is merely speculation and requires investigation.

Beyond fungal and bacterial decomposers, soil fauna play an important role in soil detrital food webs and can have a large influence on terrestrial biogeochemical cycles (Petersen and Luxton, 1982). Fungivorous nematodes, earthworms and arthropods may favor necromass of certain species of EM fungi over others and increase the speed at which the $C$ and nutrients in those litters are cycled. Variation in grazing on various species of EM fungi may be due to variation in fungal mycelium defense and palatability. Böllmann et al. (2010) examined the effect of different defensive strategies of soil fungi on the grazing preference of Collembola and found that species producing chemical repellent metabolites (e.g. Clitocybe phyllophila, Lactarius pubescens, and Hebeloma sinapizans) deterred grazing the most while those producing crystalline structures (e.g. Piloderma croceum, Suillus flavus and Suillus luteus) also had some success at reducing grazing. Interestingly, heavily melanized fungal taxa, including $C$. geophilum, were preferred by the Collembola despite being lower in nutritional quality and harder to digest. Therefore, chemical repellents and crystalline structures likely have a stronger influence on grazer preference than nutritional quality and grazing defense strategies employed by EM fungi likely have an interactive effect with decomposer communities on the rate of EM necromass decomposition.

Important questions regarding the influence of soil decomposer communities on decomposition remain. How does the EM fungal community structure influence decomposer community structure? Does this indirectly influence EM fungal necromass decomposition and, as a consequence, SOM formation and $\mathrm{N}$ mineralization? Because EM fungi themselves produce extracellular enzymes that breakdown organic material in order to access nutrients, do EM 


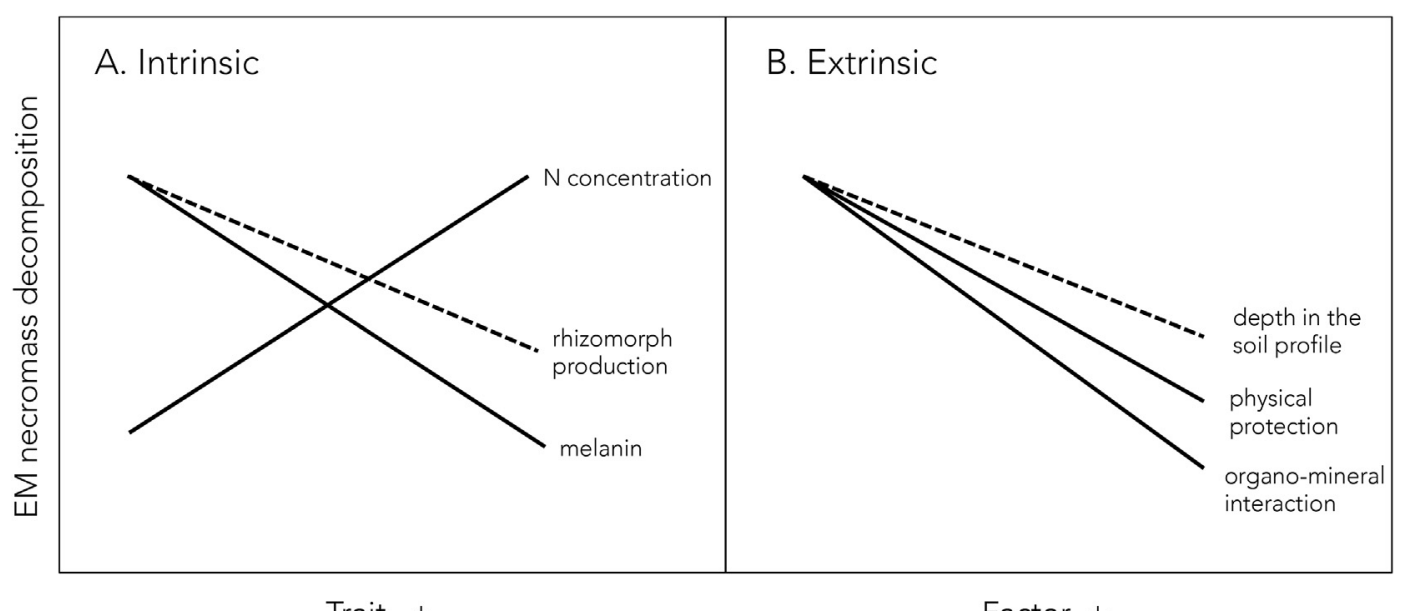

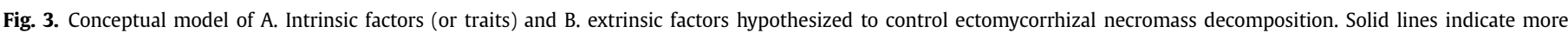

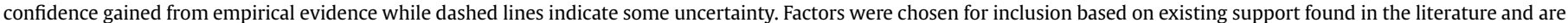

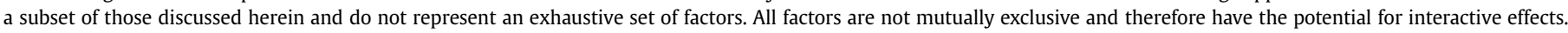

fungi directly compete with saprotrophic fungi and bacteria for resources found in their own tissues? Do EM fungi have an inherent advantage in accessing and processing these resources because they are biotrophic rather than saprotrophic?

\section{Conclusions}

Significant progress has been made in the past 10 years in our understanding and appreciation of the contribution of EM fungal necromass to forest biogeochemical cycles (Fernandez and Kennedy, 2015). In this review we highlight the importance of understanding EM fungal species differences in the decomposability of their tissues. Though this area of research is still relatively young, this synthesis of the existing literature allows us to draw some tentative conclusions about the factors controlling the decomposition of EM fungal necromass (Fig. 3). Recent studies have shown a great deal of variation in EM fungal necromass decomposability and suggest that differences in biochemistry play a large role. While once hypothesized to be a relatively recalcitrant fungal cell wall component, chitin concentration may actually contribute positively to the decomposability of EM fungal necromass. However, melanin concentration appears to govern the quality of EM fungal necromass much like lignin concentration does in plant litters. At the same time, decomposability of EM fungal necromass appears to be positively controlled by the $\mathrm{N}$ concentration. Together, melanin and $\mathrm{N}$ concentrations may explain a large fraction of the variation in decomposition rates observed among EM fungal necromass much like lignin and $\mathrm{N}$ concentrations do for plant litter decomposition.

Thus far, much of the research focused on fungal necromass decomposition has used lab grown fungal biomass and either used to inoculate soil microcosms (i.e. Wilkinson et al., 2011; Drigo et al., 2012) or used in a litterbag approach (i.e. Fernandez and Koide, 2012; Fernandez and Koide, 2014). While valuable information has been gained from these approaches, they do not necessarily reflect the production and decomposition of mycelia in situ. Furthermore, lab-grown fungal biomass may represent substrates that are artificially high in quality since resources are generally not limiting in culture conditions. Because the physiochemical properties of fungal tissue grown in cultures may differ from those grown under more natural conditions, we must begin to examine the turnover and decomposition of fungal tissues in situ to gain a better understanding of the differences in persistence of EM necromass (Fernandez et al., 2013). As the advancement of minirhizotron imaging technologies allows finer resolutions (Allen and Kitajima, 2013), investigators should be able to identify traits associated with fungi and relate them to persistence in the soil. These data will also allow for finer contrasts between EM fungal structures in situ. Finally, these imaging tools should be useful in elucidating extrinsic factors controlling decomposition rates of EM fungal necromass. A major goal of this area of research will be to explore the linkages between EM fungal community structure and biogeochemical cycling. For instance, do mono-dominant communities have distinctly different contributions to SOM formation than more diverse communities? It should be restated that minirhizotron techniques are only able to track the production and persistence of soil structures and cannot distinguish between the effects of lifespan and resistance to degradation; therefore care should be taken when generating conclusions about persistence. Ultimately, it will be important to link factors controlling the decomposition of necromass to SOM-formation. For instance, relatively labile compounds are often found to contribute to SOMformation suggesting that biochemistry is not the only factor driving SOM accumulation and extrinsic factors such as physical and physiochemical protection from soil may be driving $C$ sequestration in soils (Schmidt et al., 2011; Cotrufo et al., 2013). However, it is important to appreciate the likely possibility of multiple interacting factors, perhaps operating on different timescales, which ultimately determine the incorporation of EM fungal necromass into SOM. Litterbag experiments do not allow the investigator to trace the $\mathrm{C}$ in necromass into stable SOM pools and therefore are unable to examine these types of questions. Coupling next generation molecular, stable isotope probing and highresolution chemistry analytical techniques is a promising approach to begin to address these questions. Exploring these linkages will be invaluable in understanding the role that EM fungal necromass plays in terrestrial biogeochemical cycles.

\section{Acknowledgments}

We would like to thank D. Eissenstat, J. Kaye, and E. Smithwick, D. Coleman and two anonymous reviewers for their helpful comments on previous versions of this manuscript. Funding to CWF was provided by the Alfred P. Sloan Foundation and The College of 
Agriculture Sciences at the Pennsylvania State University. Funding to RTK was provided by the US Department of Agriculture-NIFAAFRI (2011-67003-30343, 2011-67009-20072), the US National Science Foundation (IOS 1120482), and Brigham Young University.

\section{References}

Aerts, R., 1997. Climate, leaf litter chemistry and leaf litter decomposition in terrestrial ecosystems: a triangular relationship. Oikos 79, 439-449.

Agerer, R., 2001. Exploration types of ectomycorrhizae. Mycorrhiza 11, 107-114.

Allen, M.F., Kitajima, K., 2013. In situ high-frequency observations of mycorrhizas. New Phytologist 200, 222-228.

Allen, M.F., Kitajima, K., 2014. Net primary production of ectomycorrhizas in a California forest. Fungal Ecology 10, 81-90.

Averill, C., Turner, B.L., Finzi, A.C., 2014. Mycorrhiza-mediated competition between plants and decomposers drives soil carbon storage. Nature 505, 543-545.

Bartnicki-Garcia, S., 1968. Cell wall chemistry, morphogenesis, and taxonomy of fungi. Annual Reviews in Microbiology 22, 87-108.

Bell, A.A., Wheeler, M.H., 1986. Biosynthesis and functions of fungal melanins. Annual Review of Phytopathology 24, 411-451.

Berg, B., 1984. Decomposition of root litter and some factors regulating the process: long-term root litter decomposition in a Scots pine forest. Soil Biology and Biochemistry 16, 609-617.

Bogeat-Triboulot, M.B., Bartoli, F., Garbaye, J., Marmeisse, R., Tagu, D., 2004. Fungal ectomycorrhizal community and drought affect root hydraulic properties and soil adherence to roots of Pinus pinaster seedlings. Plant and Soil 267, 213-223.

Böllmann, J., Elmer, M., Wöllecke, J., Raidl, S., Hüttl, R.F., 2010. Defensive strategies of soil fungi to prevent grazing by Folsomia candida (Collembola). Pedobiologia 53, 107-114.

Bowman, S.M., Free, S.J., 2006. The structure and synthesis of the fungal cell wall. Bioessays 28, 799-808.

Brownlee, C., Duddridge, J.A., Malibari, A., Read, D.J., 1983. The structure and function of mycelial systems of ectomycorrhizal roots with special reference to their role in forming inter-plant connections and providing pathways for assimilate and water transport. Plant and Soil 71, 433-443.

Bull, A.T., 1970. Chemical composition of wild-type and mutant Aspergillus nidulans cell walls. The nature of polysaccharide and melanin constituents. Journal of General Microbiology 63, 75-94.

Burns, R.G., 1982. Enzyme activity in soil: location and a possible role in microbial ecology. Soil Biology and Biochemistry 14, 423-427.

Butler, M.J., Day, A.W., 1998a. Fungal melanins: a review. Canadian Journal of Microbiology 44, 1115-1136.

Butler, M.J., Day, A.W., 1998b. Destruction of fungal melanins by ligninases of Phanerochaete chrysosporium and other white rot fungi. International Journal of Plant Sciences 159, 989-995.

Cairney, J.W., 2012. Extramatrical mycelia of ectomycorrhizal fungi as moderators of carbon dynamics in forest soil. Soil Biology and Biochemistry 47, 198-208.

Cairney, J.W.G., Jennings, D.H., Veltkamp, C.J., 1989. A scanning electron microscope study of the internal structure of mature linear mycelial organs of four basidiomycete species. Canadian Journal of Botany 67, 2266-2271.

Carreiro, M.M., Sinsabaugh, R.L., Repert, D.A., Parkhurst, D.F. 2000. Microbia enzyme shifts explain litter decay responses to simulated nitrogen deposition. Ecology 81, 2359-2365.

Chapman, S.K., Koch, G.W., 2007. What type of diversity yields synergy during mixed litter decomposition in a natural forest ecosystem? Plant and Soil 299, $153-162$.

Chapman, S.K., Newman, G.S., Hart, S.C., Schweitzer, J.A., Koch, G.W., 2013. Leaf litter mixtures alter microbial community development: mechanisms for nonadditive effects in litter decomposition. PloS One 8, e62671.

Christias, C., Couvaraki, C., Georgopoulos, S.G., Macris, B., Vomvoyanni, V., 1975 Protein content and amino acid composition of certain fungi evaluated for microbial protein production. Applied Microbiology 29, 250-254.

Clemmensen, K.E., Bahr, A., Ovaskainen, O., Dahlberg, A., Ekblad, A., Wallander, H. Lindahl, B.D., et al., 2013. Roots and associated fungi drive long-term carbon sequestration in boreal forest. Science 339, 1615-1618.

Clemmensen, K.E., Finlay, R.D., Dahlberg, A., Stenlid, J., Wardle, D.A., Lindahl, B.D. 2015. Carbon sequestration is related to mycorrhizal fungal community shift during long-term succession in boreal forests. New Phytologist 205, 1525-1536.

Cleveland, C.C., Liptzin, D., 2007. C: N: P stoichiometry in soil: is there a "Redfield ratio" for the microbial biomass? Biogeochemistry 85, 235-252.

Cotrufo, M.F., Wallenstein, M.D., Boot, C.M., Denef, K., Paul, E., 2013. The Microbial Efficiency-Matrix Stabilization (MEMS) framework integrates plant litter decomposition with soil organic matter stabilization: do labile plant inputs form stable soil organic matter? Global Change Biology 19 (4), 988-995.

Courty, P.E., Buée, M., Diedhiou, A.G., Frey-Klett, P., Le Tacon, F., Rineau, Turpault M.P. Uroz, S., Garbaye, J., 2010. The role of ectomycorrhizal communities in forest ecosystem processes: new perspectives and emerging concepts. Soil Biology and Biochemistry 42, 679-698.

Cromack Jr., K., Sollins, P., Todd, R.L., Fogel, R., Todd, A.W., Fender, W.M., Crossley, M.E., Crossley Jr., D.A., 1977. The role of oxalic acid and bicarbonate in calcium cycling by fungi and bacteria: some possible implications for soil animals. Ecological Bulletins 25, 246-252.
Crowther, T.W., Sokol, N.W., Oldfield, E.E., Maynard, D.S., Thomas, S.M., Bradford, M.A., 2015. Environmental stress response limits microbial necromass contributions to soil organic carbon. Soil Biology and Biochemistry 85 , $153-161$.

Dahlberg, A., Jonsson, L., Nylund, J.E., 1997. Species diversity and distribution of biomass above and below ground among ectomycorrhizal fungi in an oldgrowth Norway spruce forest in south Sweden. Canadian Journal of Botany 75, 1323-1335.

Davidson, E.A., Janssens, I.A., 2006. Temperature sensitivity of soil carbon decomposition and feedbacks to climate change. Nature 440, 165-173.

Dickie, I.A., 2007. Host preference, niches and fungal diversity. New Phytologist 174 (2), 230-233.

Dickie, I.A., Xu, B., Koide, R.T., 2002. Vertical niche differentiation of ectomycorrhizal hyphae in soil as shown by T-RFLP analysis. New Phytologist 156, 527-535.

Drigo, B., Anderson, I.C., Kannangara, G.S.K., Cairney, J.W.G., Johnson, D., 2012. Rapid incorporation of carbon from ectomycorrhizal mycelial necromass into soil fungal communities. Soil Biology and Biochemistry 49, 4-10.

Dunham, S.M., Larsson, K.H., Spatafora, J.W., 2007. Species richness and community composition of mat-forming ectomycorrhizal fungi in old-and second-growth Douglas-fir forests of the HJ Andrews Experimental Forest, Oregon, USA. Mycorrhiza 17, 633-645.

Ekblad, A., Wallander, H., Näsholm, T., 1998. Chitin and ergosterol combined to measure total and living fungal biomass in ectomycorrhizas. New Phytologist $138,143-149$.

Ekblad, A., Wallander, H., Godbold, D.L., Cruz, C., Johnson, D., Baldrian, P., Björk, R.G., Epron, D., Kieliszewska-Rokicka, B., Kjøller, R., Matzner, E., Neumann, J., Plassard, C., 2013. The production and turnover of extramatrical mycelium of ectomycorrhizal fungi in forest soils: role in carbon cycling. Plant and Soil 366, $1-27$.

Feofilova, E.P., 2010. The fungal cell wall: modern concepts of its composition and biological function. Microbiology 79, 711-720.

Fernandez, C.W., Kennedy, P.G., 2015. Moving beyond the black-box: fungal traits, community structure, and carbon sequestration in forest soils. New Phytologist 205, 1378-1380.

Fernandez, C.W., Koide, R.T., 2012. The role of chitin in the decomposition of ectomycorrhizal fungal necromass. Ecology 93, 24-28.

Fernandez, C.W. Koide, R.T., 2013. The function of melanin in the ectomycorrhizal fungus Cenococcum geophilum under water stress. Fungal Ecology 6, 479-486.

Fernandez, C.W., Koide, R.T., 2014. Initial melanin and nitrogen concentrations control the decomposition of ectomycorrhizal fungal necromass. Soil Biology and Biochemistry 77, 150-157.

Fernandez, C.W., McCormack, M.L., Hill, J.M., Pritchard, S.G., Koide, R.T., 2013. On the persistence of Cenococcum geophilum ectomycorrhizas and its implications for forest carbon and nutrient cycles. Soil Biology and Biochemistry 65, $141-143$.

Fierer, N., Craine, J.M., McLauchlan, K., Schimel, J.P., 2005. Litter quality and the temperature sensitivity of decomposition. Ecology 86, 320-326.

Fitter, A.H., Garbaye, J., 1994. Interactions between mycorrhizal fungi and other soil organisms. Plant and Soil 159, 123-132.

Fogel, R., 1980. Mycorrhizae and nutrient cycling in natural forest ecosystems. New Phytologist 86, 199-212.

Fogel, R., Hunt, G., 1983. Contribution of mycorrhizae and soil fungi to nutrient cycling in a Douglas-fir ecosystem. Canadian Journal of Forest Research 13, 219-232.

Fomina, M., Gadd, G.M., 2003. Metal sorption by biomass of melanin-producing fungi grown in clay-containing medium. Journal of Chemical Technology and Biotechnology 78, 23-34.

Frey, S.D., Knorr, M., Parrent, J.L., Simpson, R.T., 2004. Chronic nitrogen enrichment affects the structure and function of the soil microbial community in temperate hardwood and pine forests. Forest Ecology and Management 196, 159-171.

Garrido, N., Becerra, J., Marticorena, C., Oehrens, E., Silva, M., Horak, E., 1982 Antibiotic properties of ectomycorrhizae and saprophytic fungi growing on Pinus radiata D. Don I. Mycopathologia 77, 93-98.

Gartner, T.B., Cardon, Z.G., 2004. Decomposition dynamics in mixed-species leaf litter. Oikos 104, 230-246.

Gill, R.A., Burke, I.C., 2002. Influence of soil depth on the decomposition of Bouteloua gracilis roots in the shortgrass steppe. Plant and Soil 241, 233-242.

Godbold, D.L. Hoosbeek, M.R., Lukac, M., Cotrufo, M.F., Janssens, I.A., Ceulemans, R. Peressotti, A., et al., 2006. Mycorrhizal hyphal turnover as a dominant process for carbon input into soil organic matter. Plant and Soil 281, 15-24.

Gooday, G.W., 1995. Cell walls. In: The Growing Fungus. Springer, Netherlands, pp. $43-62$.

Grandy, A.S., Neff, J.C., 2008. Molecular C dynamics downstream: the biochemical decomposition sequence and its impact on soil organic matter structure and function. Science of the Total Environment 404, 297-307.

Grandy, A.S., Robertson, G.P., 2007. Land-use intensity effects on soil organic carbon accumulation rates and mechanisms. Ecosystems 10, 59-74.

Gray, T.R.G., Baxby, P., 1968. Chitin decomposition in soil: II. The ecology of chitinoclastic micro-organisms in forest soil. Transactions of the British Mycological Society 51, 293-309.

Griffiths, R.P., Caldwell, B.A., Cromack Jr., K., Morita, R.Y., 1990. Douglas-fir forest soils colonized by ectomycorrhizal mats. I. Seasonal variation in nitrogen chemistry and nitrogen cycle transformation rates. Canadian Journal of Forest Research 20, 211-218. 
Griffiths, R.P., Bradshaw, G.A., Marks, B., Lienkaemper, G.W., 1996. Spatial distribution of ectomycorrhizal mats in coniferous forests of the Pacific Northwest, USA. Plant and Soil 180, 147-158.

Handa, I.T., Aerts, R., Berendse, F., Berg, M.P., Bruder, A., Butenschoen, O., Chauvet, E., Gessner, M.O., Jabiol, J., Makkonen, M., McKie, B.G., Malmqvist, B. Peeters, E.T.H.M., Scheu, S., Schmid, B., van Ruijven, J., Vos, V.C.A., Hättenschwiler, S., 2014. Consequences of biodiversity loss for litter decomposition across biomes. Nature 509, 218-221.

Hobbie, S.E., 1996. Temperature and plant species control over litter decomposition in Alaskan tundra. Ecological Monographs 66, 503-522.

Hobbie, E.A., 2006. Carbon allocation to ectomycorrhizal fungi correlates with belowground allocation in culture studies. Ecology 87, 563-569.

Hobbie, J.E., Hobbie, E.A., 2006. 15N in symbiotic fungi and plants estimates nitrogen and carbon flux rates in Arctic tundra. Ecology 87, 816-822.

Hobbie, E.A., Weber, N.S., Trappe, J.M., Van Klinken, G.J., 2002. Using radiocarbon to determine the mycorrhizal status of fungi. New Phytologist 156, 129-136.

Hurst, H.M., Wagner, G.H., 1969. Decomposition of ${ }^{14}$ C-labeled cell wall and cytoplasmic fractions from hyaline and melanic fungi. Soil Science Society of America Journal 33, 707-711.

Jonsson, M., Wardle, D.A., 2008. Context dependency of litter-mixing effects on decomposition and nutrient release across a long-term chronosequence. Oikos 117, 1674-1682.

Joslin, J.D., Gaudinski, J.B., Torn, M.S., Riley, W.J., Hanson, P.J., 2006. Fine-root turnover patterns and their relationship to root diameter and soil depth in a ${ }^{14}$ C-labeled hardwood forest. New Phytologist 172, 523-535.

Kätterer, T., Bolinder, M.A., Andrén, O., Kirchmann, H., Menichetti, L., 2011. Roots contribute more to refractory soil organic matter than above-ground crop residues, as revealed by a long-term field experiment. Agriculture, Ecosystems \& Environment 141, 184-192.

Keiluweit, M., Bougoure, J.J., Nico, P.S., Pett-Ridge, J., Weber, P.K., Kleber, M., 2015. Mineral protection of soil carbon counteracted by root exudates. Nature Climate Change 5, 588-595.

Kejžar, A., Gobec, S., Plemenitaš, A., Lenassi, M., 2013. Melanin is crucial for growth of the black yeast Hortaea werneckii in its natural hypersaline environment. Fungal Biology 117, 368-379.

Keller, N.P., Turner, G., Bennett, J.W., 2005. Fungal secondary metabolism-from biochemistry to genomics. Nature Reviews Microbiology 3, 937-947.

Kerley, S.J., Read, D.J., 1998. The biology of mycorrhiza in the Ericaceae. XX. Plant and mycorrhizal necromass as nitrogenous substrates for the ericoid mycorrhizal fungus Hymenoscyphus ericae and its host. New Phytologist 139, $353-360$.

Kikuchi, J., Futai, K., 2003. Spatial distribution of sporocarps and the biomass of ectomycorrhizas of Suillus pictus in a Korean pine (Pinus koraiensis) stand. Journal of Forest Research 8, 17-25.

Kirk, T.K., Farrell, R.L., 1987. Enzymatic "combustion": the microbial degradation of lignin. Annual Reviews in Microbiology 41, 465-501.

Kluber, L.A., Tinnesand, K.M., Caldwell, B.A., Dunham, S.M., Yarwood, R.R., Bottomley, P.J., Myrold, D.D., 2010. Ectomycorrhizal mats alter forest soil biogeochemistry. Soil Biology and Biochemistry 42, 1607-1613.

Kluber, L.A., Smith, J.E., Myrold, D.D., 2011. Distinctive fungal and bacterial communities are associated with mats formed by ectomycorrhizal fungi. Soil Biology and Biochemistry 43, 1042-1050.

Kogej, T., Stein, M., Volkmann, M., Gorbushina, A.A., Galinski, E.A., GundeCimerman, N., 2007. Osmotic adaptation of the halophilic fungus Hortaea werneckii: role of osmolytes and melanization. Microbiology 153, $4261-4273$.

Kögel-Knabner, I., 2002. The macromolecular organic composition of plant and microbial residues as inputs to soil organic matter. Soil Biology and Biochemistry 34, 139-162.

Koide, R.T., Malcolm, G.M., 2009. N concentration controls decomposition rates of different strains of ectomycorrhizal fungi. Fungal Ecology 2, 197-202.

Koide, R.T., Fernandez, C.W., Peoples, M.S., 2011. Can ectomycorrhizal colonization of Pinus resinosa roots affect their decomposition? New Phytologist 191, $508-514$.

Krupa, S., Fries, N., 1971. Studies on ectomycorrhizae of pine. I. Production of volatile organic compounds. Canadian Journal of Botany 49, 1425-1431.

Krywolap, G.N., Casida Jr., L.E., 1964. An antibiotic produced by the mycorrhizal fungus Cenococcum graniforme. Canadian Journal of Microbiology 10, $365-370$.

Kuo, M.J., Alexander, M., 1967. Inhibition of the lysis of fungi by melanins. Journal of Bacteriology 94, 624-629.

Kyanko, M.V., Canel, R.S., Ludemann, V., Pose, G., Wagner, J.R., 2013. ß-Glucan content and hydration properties of filamentous fungi. Applied Biochemistry and Microbiology 49, 41-45.

Langley, J.A., Hungate, B.A., 2003. Mycorrhizal controls on belowground litter quality. Ecology 84, 2302-2312.

Langley, J.A., Chapman, S.K., Hungate, B.A., 2006. Ectomycorrhizal colonization slows root decomposition: the post-mortem fungal legacy. Ecology Letters 9 , 955-959.

Lilleskov, E.A., Bruns, T.D., Horton, T.R., Taylor, D., Grogan, P., 2004. Detection of forest stand-level spatial structure in ectomycorrhizal fungal communities. FEMS Microbiology Ecology 49, 319-332.

Lindahl, B.O., Taylor, A.F., Finlay, R.D., 2002. Defining nutritional constraints on carbon cycling in boreal forests-towards a lessphytocentric'perspective. Plant and Soil 242, 123-135.
Lindahl, B.D., Ihrmark, K., Boberg, J., Trumbore, S.E., Högberg, P., Stenlid, J., Finlay, R.D., 2007. Spatial separation of litter decomposition and mycorrhizal nitrogen uptake in a boreal forest. New Phytologist 173, 611-620.

Makkonen, M., Berg, M.P., van Logtestijn, R.S., van Hal, J.R., Aerts, R., 2012. Do physical plant litter traits explain non-additivity in litter mixtures? A test of the improved microenvironmental conditions theory. Oikos 122, 987-997.

Malik, K.A., Haider, K., 1982. Decomposition of ${ }^{14}$ C-labelled melanoid fungal residues in a marginally sodic soil. Soil Biology and Biochemistry 14, 457-460.

Manzoni, S., Trofymow, J.A., Jackson, R.B., Porporato, A., 2010. Stoichiometric controls on carbon, nitrogen, and phosphorus dynamics in decomposing litter. Ecological Monographs 80, 89-106.

Markkola, A.M., Tarvainen, O., Ahonen-Jonnarth, U., Strömmer, R., 2002. Urban polluted forest soils induce elevated root peroxidase activity in Scots pine (Pinus sylvestris L.) seedlings. Environmental Pollution 116, 273-278.

Marx, D.H., 1972. Ectomycorrhizae as biological deterrents to pathogenic root infections. Annual Review of Phytopathology 10, 429-454.

McCormack, M.L., Pritchard, S.G., Breland, S., Davis, M.A., Prior, S.A., Runion, G.B., Mitchel, R.J., Rogers, H.H., 2010. Soil fungi respond more strongly than fine roots to elevated $\mathrm{CO}_{2}$ in a model regenerating longleaf pine-wiregrass ecosystem. Ecosystems 13, 901-916.

McCormack, M.L., Dickie, I.A., Eissenstat, D.M., Fahey, T.J., Fernandez, C.W., Guo, D., Zadworny, M., et al., 2015. Redefining fine roots improves understanding of below-ground contributions to terrestrial biosphere processes. New Phytologist 207, 505-518.

Meentemeyer, V., 1978. Macroclimate and lignin control of litter decomposition rates. Ecology 59, 465-472.

Meier, I.C., Pritchard, S.G., Brzostek, E.R., McCormack, M.L., Phillips, R.P., 2015. The rhizosphere and hyphosphere differ in their impacts on carbon and nitrogen cycling in forests exposed to elevated $\mathrm{CO}_{2}$. New Phytologist 205, 1164-1174.

Melillo, J.M., Aber, J.D., Muratore, J.F., 1982. Nitrogen and lignin control of hardwood leaf litter decomposition dynamics. Ecology 63, 621-626.

Miller, S.L., Torres, P., McClean, T.M., 1994. Persistence of basidiospores and sclerotia of ectomycorrhizal fungi and Morchella in soil. Mycologia 89-95.

Moucawi, J., Fustec, E., Jambu, P., Jacquesy, R., 1981. Decomposition of lipids in soils: free and esterified fatty acids, alcohols and ketones. Soil Biology and Biochemistry 13, 461-468.

Nagy, N.E., Fossdal, C.G., 2013. Host responses in Norway spruce roots induced to the pathogen Ceratocystis polonica are evaded or suppressed by the ectomycorrhizal fungus Laccaria bicolor. Plant Biology 15, 99-110.

Nakas, J.P., Klein, D.A., 1979. Decomposition of microbial cell components in a semiarid grassland soil. Applied and Environmental Microbiology 38, 454-460.

Napoli, C., Mello, A., Borra, A., Vizzini, A., Sourzat, P., Bonfante, P., 2010. Tuber melanosporum, when dominant, affects fungal dynamics in truffle grounds. New Phytologist 185, 237-247.

Nelson, D.W., Martin, J.P., Ervin, J.O., 1979. Decomposition of microbial cells and components in soil and their stabilization through complexing with model humic acid-type phenolic polymers. Soil Science Society of America Journal 43, 84-88.

Nguyen, N.H., Hynson, N.A., Bruns, T.D., 2012. Stayin'alive: survival of mycorrhizal fungal propagules from 6-yr-old forest soil. Fungal Ecology 5, 741-746.

O'Connell, A.M., 1990. Microbial decomposition (respiration) of litter in eucalypt forests of south-western Australia: an empirical model based on laboratory incubations. Soil Biology and Biochemistry 22, 153-160.

Olander, L.P., Vitousek, P.M., 2000. Regulation of soil phosphatase and chitinase activity by N and P availability. Biogeochemistry 49, 175-191.

Orwin, K.H., Kirschbaum, M.U., St John, M.G., Dickie, I.A., 2011. Organic nutrient uptake by mycorrhizal fungi enhances ecosystem carbon storage: a modelbased assessment. Ecology Letters 14, 493-502.

Petersen, H., Luxton, M., 1982. A comparative analysis of soil fauna populations and their role in decomposition processes. Oikos 39, 288-388.

Pickles, B.J., Genney, D.R., Potts, J.M., Lennon, J.J., Anderson, I.C., Alexander, I.J., 2010. Spatial and temporal ecology of Scots pine ectomycorrhizas. New Phytologist 186, 755-768.

Pigott, C.D., 1982. Fine structure of mycorrhiza formed by Cenococcum geophilum Fr. on Tilia cordata Mill. New Phytologist 92, 501-512.

Pritchard, S.G., Strand, A.E., McCormack, M.L., Davis, M.A., Oren, R., 2008. Mycorrhizal and rhizomorph dynamics in a loblolly pine forest during 5 years of freeair- $\mathrm{CO}_{2}$-enrichment. Global Change Biology 14, 1252-1264.

Rasanayagam, S., Jeffries, P., 1992. Production of acid is responsible for antibiosis by some ectomycorrhizal fungi. Mycological Research 96, 971-976.

Read, D.J., 1991. Mycorrhizas in ecosystems. Experientia 47, 376-391.

Read, D.J., Perez-Moreno, J., 2003. Mycorrhizas and nutrient cycling in ecosystems-a journey towards relevance? New Phytologist 157, 475-492.

Rehnstrom, A.L., Free, S.J., 1996. The isolation and characterization of melanindeficient mutants of Monilinia fructicola. Physiological and Molecular Plant Pathology 49, 321-330.

Rillig, M.C., 2004. Arbuscular mycorrhizae, glomalin, and soil aggregation. Canadian Journal of Soil Science 84, 355-363.

Rillig, M.C., Mummey, D.L., 2006. Mycorrhizas and soil structure. New Phytologist $171,41-53$.

Rillig, M.C., Caldwell, B.A., Wösten, H.A., Sollins, P., 2007. Role of proteins in soil carbon and nitrogen storage: controls on persistence. Biogeochemistry 85 , 25-44.

Rillig, M.C., Aguilar-Trigueros, C.A., Bergmann, J., Verbruggen, E., Veresoglou, S.D., Lehmann, A., 2015. Plant root and mycorrhizal fungal traits for understanding soil aggregation. New Phytologist 205, 1385-1388. 
Rosas, Á.L., Casadevall, A., 1997. Melanization affects susceptibility of Cryptococcus neoformans to heat and cold. FEMS Microbiology Letters 153, 265-272.

Rosling, A., Landeweert, R., Lindahl, B.D., Larsson, K.H., Kuyper, T.W., Taylor, A.F.S., Finlay, R.D., 2003. Vertical distribution of ectomycorrhizal fungal taxa in a podzol soil profile. New Phytologist 159, 775-783.

Ruiz-Herrera, J., 1992. Fungal Cell Wall: Structure, Synthesis, and Assembly. CRC Press.

Russell, A.E., 2014. Unexpected effects of chitin, cellulose, and lignin addition on soil dynamics in a wet tropical Forest. Ecosystems 17, 918-930.

Saltarelli, R., Ceccaroli, P., Vallorani, L., Zambonelli, A., Citterio, B., Malatesta, M., Stocchi, V., 1998. Biochemical and morphological modifications during the growth of Tuber borchii mycelium. Mycological Research 102, 403-409.

Schmidt, M.W., Torn, M.S., Abiven, S., Dittmar, T., Guggenberger, G., Janssens, I.A Trumbore, S.E., et al., 2011. Persistence of soil organic matter as an ecosystem property. Nature 478, 49-56.

Schweigert, M., Herrmann, S., Miltner, A., Fester, T., Kästner, M., 2015. Fate of ectomycorrhizal fungal biomass in a soil bioreactor system and its contribution to soil organic matter formation. Soil Biology and Biochemistry 88, 120-127.

Silver, W.L., Miya, R.K., 2001. Global patterns in root decomposition: comparisons of climate and litter quality effects. Oecologia 129, 407-419.

Sinsabaugh, R.L., Carreiro, M.M., Repert, D.A., 2002. Allocation of extracellular enzymatic activity in relation to litter composition, $\mathrm{N}$ deposition, and mass loss. Biogeochemistry 60, 1-24.

Sinsabaugh, R.L., Hill, B.H., Shah, J.J.F., 2009. Ecoenzymatic stoichiometry of microbial organic nutrient acquisition in soil and sediment. Nature 462, 795-798.

Six, J., Frey, S.D., Thiet, R.K., Batten, K.M., 2006. Bacterial and fungal contributions to carbon sequestration in agroecosystems. Soil Science Society of America Journal 70, 555-569.

Smiderle, F.R., Olsen, L.M., Ruthes, A.C., Czelusniak, P.A., Santana-Filho, A.P. Sassaki, G.L., Iacomini, M., et al., 2012. Exopolysaccharides, proteins and lipids in Pleurotus pulmonarius submerged culture using different carbon sources. Carbohydrate Polymers 87, 368-376.

Smith, M.E., Henkel, T.W., Rollins, J.A., 2015. How many fungi make sclerotia? Fungal Ecology 13, 211-220.

Steinberg, P.D., Rillig, M.C., 2003. Differential decomposition of arbuscular mycorrhizal fungal hyphae and glomalin. Soil Biology and Biochemistry 35, 191-194.

Strickland, M.S., Lauber, C., Fierer, N., Bradford, M.A., 2009a. Testing the functional significance of microbial community composition. Ecology 90, 441-451.

Strickland, M.S., Osburn, E., Lauber, C., Fierer, N., Bradford, M.A., 2009b. Litter quality is in the eye of the beholder: initial decomposition rates as a function of inoculum characteristics. Functional Ecology 23, 627-636.

Talbot, J.M., Treseder, K.K., 2012. Interactions among lignin, cellulose, and nitrogen drive litter chemistry-decay relationships. Ecology 93, 345-354.

Talbot, J.M., Bruns, T.D., Smith, D.P., Branco, S., Glassman, S.I., Erlandson, S., Vilgalys, R., Peay, K.G., 2013. Independent roles of ectomycorrhizal and saprotrophic communities in soil organic matter decomposition. Soil Biology and Biochemistry 57, 282-291.

Taylor, A.F., Högbom, L., Högberg, M., Lyon, A.J., Näsholm, T., Högberg, P., 1997. Natural ${ }^{15} \mathrm{~N}$ abundance in fruit bodies of ectomycorrhizal fungi from boreal forests. New Phytologist 136, 713-720.

Throckmorton, H.M., Bird, J.A., Dane, L, Firestone, M.K., Horwath, W. R, 2012. The source of microbial $C$ has little impact on soil organic matter stabilisation in forest ecosystems. Ecology Letters 15, 1257-1265.

Tisdall, J.M., 1994. Possible role of soil microorganisms in aggregation in soils. Plant and Soil 159, 115-121.

Todd-Brown, K.E., Hopkins, F.M., Kivlin, S.N., Talbot, J.M., Allison, S.D., 2012. A framework for representing microbial decomposition in coupled climate models. Biogeochemistry 109, 19-33.
Treseder, K.K., Allen, M.F., 2000. Mycorrhizal fungi have a potential role in soil carbon storage under elevated $\mathrm{CO}_{2}$ and nitrogen deposition. New Phytologist 147, 189-200.

Treseder, K.K., Lennon, J.T., 2015. Fungal traits that drive ecosystem dynamics on land. Microbiology and Molecular Biology Reviews 79, 243-262.

Treseder, K.K., Allen, M.F., Ruess, R.W., Pregitzer, K.S., Hendrick, R.L., 2005. Lifespans of fungal rhizomorphs under nitrogen fertilization in a pinyon-juniper woodland. Plant and Soil 270, 249-255.

Trocha, L.K., Kałucka, I., Stasińska, M., Nowak, W., Dabert, M., Leski, T., Rudawska, M., Oleksyn, J., 2012. Ectomycorrhizal fungal communities of native and non-native Pinus and Quercus species in a common garden of 35-year-old trees. Mycorrhiza 22, 121-134.

Trofymow, J.A., Morley, C.R., Coleman, D.C., Anderson, R.V., 1983. Mineralization of cellulose in the presence of chitin and assemblages of microflora and fauna in soil. Oecologia 60, 103-110.

Unestam, T., Sun, Y.P., 1995. Extramatrical structures of hydrophobic and hydrophilic ectomycorrhizal fungi. Mycorrhiza 5, 301-311.

Vogt, K.A., Edmonds, R.L., 1980. Patterns of nutrient concentration in basidiocarps in western Washington. Canadian Journal of Botany 58, 694-698.

Vogt, K.A., Edmonds, R.L., Grier, C.C., 1981. Biomass and nutrient concentrations of sporocarps produced by mycorrhizal and decomposer fungi in Abies amabilis stands. Oecologia 50, 170-175.

Waldrop, M.P. Zak, D.R., Sinsabaugh, R.L., 2004. Microbial community response to nitrogen deposition in northern forest ecosystems. Soil Biology and Biochemistry 36, 1443-1451.

Wang, Y., Casadevall, A., 1994. Decreased susceptibility of melanized Cryptococcus neoformans to UV light. Applied and Environmental Microbiology 60, 3864-3866.

Wardle, D.A., Nilsson, M.C., Zackrisson, O., Gallet, C., 2003. Determinants of litter mixing effects in a Swedish boreal forest. Soil Biology and Biochemistry 35, 827-835.

Watanabe, M., Sato, H., Matsuzaki, H., Kobayashi, T., Sakagami, N., Maejima, Y., Ohta, H., Fujitake, N., Hiradate, S., 2007. ${ }^{14} \mathrm{C}$ ages and $\delta 13 \mathrm{C}$ of sclerotium grains found in forest soils. Soil Science and Plant Nutrition 53, 125-131.

Wessels, J.G.H., 1994. Developmental regulation of fungal cell wall formation. Annual Review of Phytopathology 32, 413-437.

Wessels, J.G., 1996. Fungal hydrophobins: proteins that function at an interface. Trends in Plant Science 1, 9-15.

Wieder, W.R., Bonan, G.B., Allison, S.D., 2013. Global soil carbon projections are improved by modelling microbial processes. Nature Climate Change 3 , 909-912.

Wilkinson, A., Alexander, I.J., Johnson, D., 2011. Species richness of ectomycorrhizal hyphal necromass increases soil $\mathrm{CO}_{2}$ efflux under laboratory conditions. Soil Biology and Biochemistry 43, 1350-1355.

Wösten, H.A., de Vocht, M.L., 2000. Hydrophobins, the fungal coat unravelled. Biochimica et Biophysica Acta (BBA)-Reviews on Biomembranes 1469, 79-86.

Zak, J.C., Willig, M.R., Moorhead, D.L., Wildman, H.G., 1994. Functional diversity of microbial communities: a quantitative approach. Soil Biology and Biochemistry $26,1101-1108$

Zeglin, L.H., Kluber, L.A., Myrold, D.D., 2013. The importance of amino sugar turnover to $\mathrm{C}$ and $\mathrm{N}$ cycling in organic horizons of old-growth Douglas-fir forest soils colonized by ectomycorrhizal mats. Biogeochemistry 112, 679-693.

Zheng, W., Morris, E.K., Rillig, M.C., 2014. Ectomycorrhizal fungi in association with Pinus sylvestris seedlings promote soil aggregation and soil water repellency. Soil Biology and Biochemistry 78, 326-331. 